\title{
Trade Preferences and Differential Treatment of Developing Countries: A Selective Survey ${ }^{1}$
}

\author{
Bernard Hoekman \\ (World Bank, Groupe d'Economie Mondiale, Sciences Po, and CEPR) \\ Çaglar Özden \\ (World Bank)
}

Summary: Non-reciprocal trade preferences and provisions in the GATT/WTO that allow developing countries greater leeway to retain or use protectionist policies are two of the central planks of so-called special and differential treatment (SDT) for developing countries in the multilateral trading system. This paper surveys the literature on the rationales, institutional features, and economic effectiveness of SDT. A large literature has emerged on SDT in the last 50 years, by both proponents and opponents. We summarize a number of key contributions on the subject, with a special emphasis on the evaluation of the impact of SDT, especially preferential market access. The issue of SDT has become very topical again, following a period during which it was viewed as an outdated concept for the multilateral trading system. We therefore devote attention as well to a number of recent contributions that discuss (i) whether there is a continued need for SDT, and (ii) how this might be designed from both a development (recipient) objective and from the perspective of the trading system more generally. A major theme of the survey is that most of the issues that are debated today were already being discussed in the 1960s. We conclude that those who questioned the value of unilateral preferences have proven to be prescient.

Keywords: Trade preferences; special and differential treatment JEL: F13, F15

\section{World Bank Policy Research Working Paper 3566, April 2005}

The Policy Research Working Paper Series disseminates the findings of work in progress to encourage the exchange of ideas about development issues. An objective of the series is to get the findings out quickly, even if the presentations are less than fully polished. The papers carry the names of the authors and should be cited accordingly. The findings, interpretations, and conclusions expressed in this paper are entirely those of the authors. They do not necessarily represent the view of the World Bank, its Executive Directors, or the countries they represent. Policy Research Working Papers are available online at http://econ.worldbank.org.

\footnotetext{
${ }^{1}$ This paper was written as the Introduction to a volume of readings on trade preferences and special and differential treatment in the GATT/WTO prepared for Edward Elgar. We are grateful to Kym Anderson, Patrick Low, Sheila Page and Chris Stevens for helpful suggestions.
} 
Members of the World Trade Organization launched a new "round" of multilateral trade negotiations in November 2001 at the Doha Ministerial Conference. The round is formally called the Doha Development Agenda, reflecting the desire of many members to address development concerns in the multilateral trading system. Defining the “development dimension" of the WTO is a major challenge. No consensus exists on whether and how to do this. All would agree that development requires sustained economic growth. If greater trade opportunities increase growth-something many (including the present authors) believe is the case - the WTO process of gradual, negotiated liberalization supports development. However, the existence of such a link remains a strongly debated issue, and many also argue that in specific circumstances there is a development rationale for trade interventions. ${ }^{2}$ Indeed, for many years the GATT took the latter view: many of its provisions allow developing countries wide leeway to retain protectionist policies. This became one of the central elements of socalled special and differential treatment (SDT) policies for developing countries within the GATT regime.

The underlying ideas were elaborated, most notably, by Raúl Prebisch and Hans Singer in the late 1950s and early 1960s. Their main argument is that developing countries need to foster industrial capacity in non-traditional manufactures both to reduce import dependence and to diversify away from traditional commodities, which were subject to declining terms of trade in the long-term and adversely volatile prices in the short-term. Part of the recommended policy prescription was high trade barriers to protect infant industries - i.e., import-substitution industrialization.

At the same time, it was recognized that exports were important as a source of foreign exchange and that the local market is generally too small for domestic industry to capture economies of scale that accompany industrial expansion. The second facet of the SDT agenda, therefore, revolved around preferential market access - a general system of trade preferences that would give developing countries better than Most Favored Nation (MFN) treatment in the markets of the industrialized countries. The Generalized System

\footnotetext{
${ }^{2}$ One thing that virtually everyone does agree on is that trade is not a sufficient condition for development, not withstanding straw men-type arguments to the contrary that are sometimes found in the literature.
} 
of Preferences (GSP), the framework to provide such preferences, was established under United Nations Conference on Trade and Development (UNCTAD) auspices in 1968. ${ }^{3}$

We focus on the rationale, institutional features, and economic effectiveness of SDT. Our aim is not to be exhaustive. A large literature has emerged on SDT in the last 50 years, by both proponents and opponents. Instead, we collect a number of key contributions on the subject, with a special emphasis on the evaluation of the impact of SDT, especially preferential market access. The issue of SDT became very topical again in recent years after a period during which SDT was viewed as an outdated concept for the multilateral trading system. In order to reflect the re-emerging policy interest in SDT, we have made an effort to include a number of recent contributions that discuss (i) whether there is a continued need for SDT, and (ii) how this might be designed from both a development (recipient) objective and from the perspective of the trading system more generally. An important question confronting the WTO members is whether the basic principle of the GATT/WTO regime - nondiscrimination — should continue to be hollowed out by policies that advocate active discrimination against some members (including many developing countries) in order to provide "better" market access to other developing countries_- "aid through trade" (Panagariya, 2003b).

We do not discuss articles analyzing the economic effects of specific GATT provisions that grant developing countries greater leeway to protect their markets. There are numerous provisions that permit this - e.g., Article XVIII, which was amended in the 1955 GATT review session, allows developing countries to use quantitative trade restrictions for balance-of-payments purposes and infant industry protection. This is because there is a large literature on such policies, and specific instruments that are covered by the GATT/WTO are covered in other volumes. ${ }^{4}$ For the same reason we have not included analyses of discriminatory quota regimes such as the Multifibre Arrangement or the preferential quota access that has been granted by the EU to certain developing countries for commodities such as bananas and sugar. In practice, such nontariff trade policies have had major impacts both in terms of distorting world trade flows and generating benefits and costs for both preferred and excluded countries. Indeed, most

\footnotetext{
${ }^{3}$ UNCTAD was founded in 1964, with Raúl Prebisch as the first Secretary-General.

${ }^{4}$ Anderson and Hoekman (forthcoming), Bown (forthcoming), and Ethier and Hillman (forthcoming).
} 
unilateral preference programs were designed to allow exports of certain developing countries to overcome protectionist policies in developed countries. For example, CBI (Caribbean Basin Initiative) and AGOA (African Growth and Opportunity Act) mainly granted preferences in apparel sectors which were restricted by MFA quotas and the main beneficiaries of the EBA (Everything But Arms) Initiative are (will be) certain agricultural products—e.g., sugar.

\section{Original Motivation, Early Critiques and Implications for the GATT}

The first contribution is UNCTAD (1964), a report written under Prebisch's direction. It outlines the arguments in favor of trade preferences in detail. The main role of unilateral preferences is to support infant-industry policies and the expansion of exports in manufactures is only a part of the overall industrialization process. The report recognizes that preferences clash with two principles of the GATT-based multilateral trade regime: reciprocity (the main instrument through which free riding is prevented when commitments to lower trade barriers are made) and non-discrimination (the MFN rule). Indeed, the report notes the potential negative impact unilateral trade preferences might have on multilateral MFN-based trade liberalization efforts. It also foresees one of the problems that has plagued the implementation of SDT in the GATT/WTO over the decades, namely, which countries should be eligible? It is argued that competition amongst developing countries might limit the overall benefits, and that the duration of preferences and graduation needed to be decided carefully. The report supports the notion that preference margins should decrease as the income levels of beneficiaries increased, and recognizes that administrative issues such as documentary requirements could reduce the benefits of preference programs.

Gardner Patterson (1965) elaborates in detail many of the criticisms that have been raised repeatedly against preferences in the following decades. He questions whether preferences are an efficient way to help the developing countries, noting that producers in beneficiary countries need to compete with domestic producers in the donor country as well as other exporters. He asks how many products there are for which a 5-7 percent preference margin would make a significant difference - the GSP involved tariff preferences, not duty- and quota-free access of the type that is now accorded to the least 
developed countries (LDCs). ${ }^{5}$ Furthermore, even in sectors where preferences would make a difference, they might lead to specialization in products where the beneficiary country did not have inherent comparative advantage, resulting in socially wasteful investment. Other costs of preferences that are identified include political frictions among beneficiary and excluded countries, especially among developing countries that are at different stages of development; administrative costs, possibly prohibitive, especially due to rules of origin; and attenuated incentives for multilateral MFN liberalization-not only might beneficiary countries cease to press for liberalization, they might actually oppose it since it would imply erosion of their preference margins. He notes that parliaments such as the US Congress would have to get involved in the process of granting preferences, which might open the gates for other protectionist pressures. In short, Patterson concludes that the costs of implementing preferences would be higher than the benefits in the thenprevailing situation.

Another early evaluation of the likely impacts of preferences is Johnson (1967). He identifies a number of additional problems, but is not as pessimistic as Patterson. Among the arguments made against preferences he repeats that (i) political conflicts among and between developed and developing countries due to trade diversion are likely, ${ }^{6}$ and (ii) that administrative costs of implementing and monitoring preferences can be high. Johnson argues that the true metric for determining the net benefits is the extent to which the effective rate of protection is lowered through preferences. Johnson also draws attention to a critical economic difference between infant industry protection and preferences. The former is a transfer from consumers to producers in the developing country. In the latter case the transfer is from the consumers in the developed country. Johnson also notes that preferences will yield the highest benefits to developing countries

\footnotetext{
${ }^{5}$ A group of the poorest countries that is defined by the United Nations, with inclusion based on specific criteria. At the time of writing there were 49 LDCs.

${ }^{6}$ The case of the dispute that arose at the 2001 WTO ministerial meeting at Doha provides an example of such tensions, ACP members sought an extension of the GATT waiver for their preferences. Eventually the debate - which pitted non-ACP developing country exporters against ACP preference beneficiariesled to a deal, but it was a good illustration of how preferences can create conflicts amongst developing countries. In this case, Thailand and the Philippines eventually joined the consensus to grant a waiver for EU preferences for ACP countries only after the EU agreed to consultations on the impact of these preferences on their exports of canned tuna (under the waiver, ACP countries would continue to be exempt from the 24 percent tariff applied to all other imports of canned tuna). The EU ultimately agreed to establish an MFN tariff quota on canned tuna of 25,000 tons at a 12 percent tariff, but it did so in the face of opposition in ACP countries.
} 
in sectors that are the most protected in developed countries - making it difficult to implement meaningful preference schemes. This was prescient, as it has been a reason why agricultural products, textiles and apparel frequently have been excluded from deep preferences. In another example of accurate foresight, Johnson was concerned that donor countries will use preferences for political purposes "to reward and punish the recipients for their behavior and performance" in non-economic areas (p.199). Johnson concludes with a call for detailed analyses to evaluate the actual impact of preferences, without taking a strong position on either side of the debate.

Subsequent researchers return again and again to the various criticisms and problems raised in these two papers. Many papers are largely efforts to comply with Johnson's recommendation for research to identify the effects of preference programs. It is striking to what extent the arguments that are made in later work are repetitive of those that were raised from the very beginning. Only very recently have theoretical arguments been put forward that advance the debate and the analysis of the economic rationales of SDT beyond what was generated in the 1960s. Most research that advanced the state of our knowledge in this area was either empirical or an exercise in applying new computational techniques and data processing power to simulate the general equilibrium effects of preferences.

The 1970s witnessed efforts to go beyond preference regimes and create a New International Economic Order (NIEO) that would favor developing countries. Elements of the NIEO included (i) additional preferential market access to developed-country markets, (ii) changes in international primary commodity markets to reduce price volatility and declines, (iii) increased foreign aid, (iv) technology transfer, and (v) revision of the international monetary system to finance the recurring deficits. Finger and Kreinin (1976) provide a critical assessment of the arguments that were made in favor of the NIEO, noting that many of the instruments that were proposed would be ineffective or counter-productive (see also Bhagwati, 1977 and Corden, 1979). As is the case with the debates on preferences that continue to this day, many of the concerns that underpinned the effort to create a NIEO continue to prevail — in particular devising stronger international mechanisms to help countries benefit from trade, the transfer of 
financial resources and technology (know how) to developing countries, and what is now called the need for "policy coherence."

Written more than two decades after the UNCTAD, Patterson and Johnson contributions, Hudec's (1987) evaluation of the costs and benefits of preferences suggests that the initial concerns raised by the critics had substance. Hudec highlights the fact that under GATT preferences were simply “permissive, not mandatory.” Since they were not contractual obligations of the donor countries, preferences were also outside the protection the GATT dispute resolution process. Hudec argues that this is among the main reasons why preferences rarely delivered the expected benefits to the developing countries. The moment beneficiary countries increased their exports considerably they would lose eligibility, either through automatic removal criteria or as a result of political pressures by the import-competing sectors within the donor country. GATT provided no recourse for them to challenge this.

As mentioned, the GSP conflicts with basic GATT rules. In recognition of this, GATT members approved special waivers for the GSP, temporarily in 1971 and permanently in 1979 through the "Enabling Clause" (part of the Tokyo Round set of Agreements). This followed the creation of a Committee on Trade and Development and the addition of several articles to the GATT that addressed development issues in the mid 1960s - the current Part IV of the GATT (on Trade and Development). Part IV encompassed the new principle that reciprocity in multilateral negotiating rounds should be limited to whatever was consistent with the development needs of developing countries (Article XXXVI). The 1979 Enabling Clause (formally Differential and More Favorable Treatment, Reciprocity and Fuller Participation of Developing Countries), gave permanent legal cover for the GSP — before then it required a waiver. The Enabling Clause included language on "graduation": SDT policies were to be phased out as the recipient countries reached a certain level of economic development. However, criteria for this were not clearly defined, as true for eligibility for SDT. Developing country status was (and remains) determined by self-declaration - the only formal group of developing countries defined in Part IV and the Enabling Clause are the LDCs. Thus, all decisions on country eligibility, product coverage and preference margins were left to the 
discretion of the preference granting countries. ${ }^{7}$ SDT provisions, including GSP, are "best endeavors" commitments; moreover, donor countries may include either trade or non-trade conditionality, de jure or de facto.

One result of the Enabling Clause and the GSP was that developing countries played only a minor role in the development of the multilateral trading system. Until the Uruguay Round negotiations of 1986-94, their participation was à la carte, and many did not make trade-liberalizing commitments in GATT negotiations (although they did over time implement unilateral trade liberalization, especially in the 1980s). With the entry into force of the WTO in 1995, the terms of their participation changed. Because of the so-called "Single Undertaking", developing countries became subject to most of the disciplines of the many agreements reached in the Uruguay Round negotiations. This was a big change for the trading system and it has had major repercussions-including a resurgence in demands for more effective SDT in the Doha round.

Before turning to the evidence on the effects of preferences and proposals for changes to SDT in the WTO, we briefly summarize the major provisions of GSP-type programs.

\section{Main Features of Unilateral Market Access Programs}

The European Union and the United States passed legislation establishing their General System of Preferences (GSP) regimes in 1971 and 1974, respectively. Although Japan, Canada, Australia and several other countries implemented their own GSP regimes, the EU and the US have been and continue to be the most important markets for the developing countries over recent decades. ${ }^{8}$

The GSP program of the United States is rather straight-forward. The program divides eligible countries into two groups based on their income levels - all developing

\footnotetext{
${ }^{7}$ Note that the Enabling Clause only exempts preference programs that apply to all developing countries or that target the LDCs. No other country discrimination in the application of preferences is formally permitted. It is for this reason that the ACP preferences required an explicit WTO waiver in 1994. Pretty much throughout the GATT period this requirement of the Enabling Clause was ignored as no member complained. This changed in the early 1990s with the report of a GATT panel dealing with the EU banana import policy. The panel found the EU regime for banana imports from ACP members violated Art. 1

GATT (MFN). Subsequently, the EU requested and obtained a waiver for the duration of Lomé convention. As the treaty ended in early 2000 , another waiver was necessary to maintain ACP preferences. As discussed, this became an issue at the Doha ministerial.

${ }^{8}$ See Onguglo (1999) for a review of existing schemes and their operation.
} 
countries and a subset of the least developed. At the time of writing, all eligible countries pay zero tariffs on around 4,650 tariff lines; LDCs have duty-free market access for an additional 1,750 lines. The 1974 Trade Act allows the President to confer GSP eligibility on any country except those that (a) do not offer reasonable and equitable market access for U.S. goods, (b) do not adequately and effectively protect U.S. intellectual property rights, (c) do not reduce trade-distorting investment policies and export practices, (d) harbor international terrorists, (e) nationalize American property without compensation, (f) are members of a commodity export cartel causing "serious disruption to the world economy," or, are (g) communist states (except those that have been granted permanent normal trading status). The law stipulates other criteria that may be used in eligibility decisions, such as (a) level of economic development, (b) protection of workers' and human rights and (c) whether the country receives preferences from other countries. Certain articles are prohibited from receiving GSP treatment. These include most textiles, watches, footwear, handbags, luggage and certain apparel.

One of the key features of the GSP program is that a specific country may lose eligibility for a specific product if its exports exceed a certain "competitive need limit," currently $\$ 110$ million per tariff line. If the country in question has a market share larger than $50 \%$ of total US imports in that category, it may also lose the GSP eligibility. ${ }^{9}$ GSP eligibility can be removed at the country, product, or country-product level. The President has discretion over when and how to apply these criteria. In practice, an Assistant US Trade Representative chairs an interagency committee which makes eligibility and graduation decisions after reviewing petitions from interested parties (the country in question, import-competing domestic firms, labor unions, other firms, human rights/environmental NGOs, etc.). Hudec (1987) concludes that a consequence is that import-competing lobby groups have made GSP a bastion of unregulated protectionism in the United States. Since the program first entered into force in 1976, 36 of the 154 eligible countries have "graduated" from the GSP program (including Singapore, Hong Kong, Taiwan, Korea, Malaysia, Mexico, and Botswana). Major countries remaining eligible include Brazil, India, Russia, Indonesia, Turkey, South Africa, and Thailand.

\footnotetext{
${ }^{9}$ However, there is a de minimis waiver. The President has the discretion to waive the Competitive Need Limit if the total imports of the US in that category from all countries (both GSP eligible and ineligible) does not exceed $\$ 16.5$ million (in 2003).
} 
The most important development in unilateral market access policies since the establishment of the GSP is the implementation of special programs that target specific countries and regions. The United States initiated the Caribbean Basin Initiative (CBI) in 1984 and modified it in 1990. Twenty-four countries in the Caribbean and Central America are eligible. The 2000 Caribbean Basin Trade Partnership Act (CBTPA), which extended preferences to textiles and apparel, passed in 2000, extended the benefits of the original program considerably. In essence, the new rules provides NAFTA-equivalent treatment for certain items (mainly apparel) which had partial preferences under the original CBI and were excluded from duty-free treatment under the GSP. The next regional program is Andean Trade Preferences Act (ATPA) which extends preferences to Bolivia, Colombia, Ecuador, and Peru. Enacted in 1991 as part of U.S. efforts to reduce narcotic production and trafficking, it was modeled after the CBI and has similar eligibility requirements and product coverage. ATPA was renewed in 2002 as the Andean Trade Promotion and Drug Eradication Act (ATPDEA) and expanded to include tuna, leather and footwear products, petroleum products, and apparel-subject, however, to restrictive rules of origin. For example, if apparel is assembled from U.S. fabrics, no quotas or duties apply, but if local inputs are used, duty-free imports are subject to a cap of 2 percent of total U.S. imports (increasing to 5 percent in equal annual installments). The final program implemented by the US is the African Growth and Opportunity Act (AGOA), passed in 2000, which offers beneficiary Sub-Saharan African countries dutyfree and quota-free market access for essentially all products. AGOA excludes textiles but extends duty- and quota-free treatment for apparel made in Africa from U.S. yarn and fabric. If regional fabric and yarn are used, there is a cap of 1.5 percent of U.S. imports, increasing to 3.5 percent over eight years. African LDCs are exempt from all rules of origin for a limited period of time, helping to significantly expand apparel exports from countries such as Lesotho. A key feature of all of these programs, including the GSP, is that they are in effect for certain period of time and need to be renewed by the Congress periodically after deliberations. In the past, GSP had lapsed twice and was reintroduced retroactively after substantial delay. These additional uncertainties about the future of preference programs further lower the incentives to invest in eligible sectors to increase export potential in the long run. 
The European Union GSP scheme, first implemented in 1971, is more complex than the US regime, but has the same basic principles. ${ }^{10}$ Whereas the United States program grants duty-free market access to all eligible products, the initial EU arrangement classified products into four groups that enjoyed different preference margins: (i) non-sensitive products were granted duty-free market access; (ii) semisensitive products had a tariff rate that is $35 \%$ of the Common Customs Tariff (CCT); (iii) sensitive products had a tariff rate of $70 \%$ of CCT and (iv) very sensitive products faced a tariff rate of $85 \%$ of CCT (EC Council Regulation No.2820/98, 21 December 1998). In 2001, this system was simplified to span only two categories - sensitive and non-sensitive. The latter group enjoys duty-free market access, and accounts for around $32 \%$ of all tariff lines. Sensitive products receive a 3.5 percentage point reduction from the applicable MFN rate. ${ }^{11}$ These products comprise around $36 \%$ of tariff lines (EC Council Regulation No.2501/01, 10 December 2001). As sensitive products are generally the ones with high MFN rates, the proportionate impact of the preference can be rather small.

Country eligibility for the EU GSP program is determined on the basis of a more codified approach than in the US, with graduation determined by "indices" that combine the development and specialization level of the country:

$$
I=\frac{\ln \left(Y_{i} / Y_{E U}\right)+\ln \left(X_{i} / X_{E U}\right)}{2}
$$

where $Y_{i}\left(Y_{E U}\right)$ is the GDP per capita in the beneficiary country (EU) and $X_{i}\left(X_{E U}\right)$ is the manufactured exports of the beneficiary country (EU) to the EU (beneficiary country). The index increases in value as the beneficiary country becomes more developed and/or runs a surplus in manufactured goods trade with the EU. It has a value of zero, for example, if the beneficiary country has the same GNP per capita as the EU and has balanced trade. If the country has GDP per capita above $\$ 8,210$ and the index has a value greater than -1 , it is automatically removed from the GSP program. South Korea, Singapore and Hong Kong, among others, were removed from the GSP program on the

\footnotetext{
${ }^{10}$ See Grilli (1997) for additional discussion of EU programs, including those for Eastern Europe and Mediterranean countries, which are reciprocal.

${ }^{11}$ For silk products and certain apparel categories, the preference margin is $20 \%$ of the MFN rate if they are in the "sensitive" category. If specific duties are applied, then they are reduced by $30 \%$. If both ad valorem and specific tariffs are applied, then the specific duty is not reduced.
} 
basis of these criteria. A second graduation criterion is country/sector-specific and is based on the extent of specialization: the relationship between the proportion of the imports in a given sector from a given country to the total $\mathrm{EU}$ imports in that sector and this country's share of total EU imports. A higher specialization index indicates that the county's exports to the EU are more concentrated in that category. As a result of this criterion, Brazil, India, China, Argentina and many other countries have lost eligibility for a wide range of product categories.

The EU GSP program has a safeguard clause that allows preferences to be suspended for certain products/countries if imports "cause or threaten to cause serious difficulties to a Community producer." The US program, in effect, has the same rule in place: any US producer can petition the USTR for any country's or product's GSP privileges to be revoked due to real or potential injury. The EU has also instituted "special incentive arrangements" that reward compliance with International Labor Organization Conventions, protection of environment and combating drug production and trafficking. Countries that benefit from these special arrangements receive additional preferences on certain products in the sensitive list. Finally, as in the US, human right violations, money laundering, corruption and violation of various international conventions on the environment may result in withdrawal of preferences.

In addition to the GSP, the EU has other preference programs, most notably preferences accorded to African, Caribbean and Pacific (ACP) under what is now the Cotonou convention. ${ }^{12}$ These countries are granted preferences that often exceed those available under the GSP. Most industrial products have duty and quota free market access whereas the preferences are less comprehensive for agricultural products. In 2000

\footnotetext{
${ }^{12}$ This is an international treaty that provides a framework for cooperation between the EU and former colonies of EU member states. The associated commitments are binding and cannot be unilaterally modified by a signatory. Thus, ACP preferences are more secure than the GSP. The Cotonou convention supercedes earlier treaties, the Yaoundé (1963-75) and Lomé (1975-99) conventions. The extent of preferential access granted under these treaties has varied over time. Under Yaoundé ACP states were required to offer reciprocal trade concessions; this was later removed under influence of the GSP. In general, preferences for agricultural products were much more limited than for manufactures. In reflection of this, under Lomé a mechanism was introduced (STABEX) to allow for compensation of ACP states if their export revenues (to the EU) for major agricultural products dropped by more than $2 \%$ of the average earnings generated over the previous four years. Under the Cotonou convention STABEX was replaced by a commitment to provide "a system of additional support in order to mitigate the adverse effects of any instability in export earnings, including in the agricultural and mining sectors, within the financial envelope for support to long-term development" (Article 68).
} 
duties were still applied to 856 tariff lines ( 837 of which were agricultural products). Of these, 116 lines were excluded from the Cotonou Agreement. An additional 301 tariff lines were eligible for reduced duties, subject to specific quantitative limits (tariff quotas) set for the ACP countries as a group. The remaining 439 products were eligible for reduced duties without quantitative limits. Another important EU program is the Everything But Arms (EBA) initiative, introduced in March 2001. This program grants duty-free access to imports of all products from the LDCs except for three major products where liberalization is delayed: fresh bananas, rice, and sugar. Tariffs on these items will be reduced gradually to zero by 2006 for bananas and by 2009 for rice and sugar, with tariff quotas for rice and sugar increased annually during the transition. A key feature of the EBA is that, in contrast to the GSP, preferences are granted for an unlimited period and are not subject to periodic review.

\section{Economic Analysis}

There has been a significant amount of econometric and simulation analysis of the effects of preferences. ${ }^{13}$ Most of this has focused on national GSP schemes which can be explained by the fact that for some time this was the predominant scheme used by developed countries. By focusing on the GSP, there is also greater scope for comparisons to be made across programs of different preference-granting countries. However, it must be kept in mind that, in practice, especially during the last 20 years or so, GSP is not the scheme that offers "most preferred" status. That is generally reserved for free trade agreement partners - who liberalize on a reciprocal basis - and subsets of "more preferred" developing countries. In the case of the EU this includes ACP and EBA eligible countries; in the case of the US better than GSP treatment is accorded under AGOA, ANDEAN and the Caribbean Basin Economic Recovery Act (CBERA). Thus, a country that trades under the GSP is actually suffering discrimination, as it is excluded from the better preference schemes available to (a subset of) its competitors. Any analysis that looks only at the GSP will therefore provide a rather distorted picture of the reality. The same is true if account is not taken of other trade policy instruments. In the case of textiles and clothing, the Multi-fiber Arrangement (MFA) for many decades established a

\footnotetext{
${ }^{13}$ See Brown (1988) for a survey of the literature up to the mid 1980s.
} 
global quota regime that restrained the more competitive developing country exporters. This regime de facto provided a preference margin for countries that were less competitive, or initially not producing these products at all since they were not bound by quotas. As noted by Page and Kleen (2004), when assessing the use of preferences, it is important that researchers consider the most valuable preferences, those that grant guaranteed prices and quotas. This is - often neglected as these guarantees are embodied in other provisions and agreements, not the GSP or other preference schemes.

Preferences can only have an impact if there is a non-zero tariff in the importing market. Two-thirds of the major items Africa exports to Canada, for example, face zero MFN tariffs; and 69\% of EU imports from Africa (by value) in 2000 were in items facing zero MFN duties (Stevens and Kennan, 2004). Thus, empirical assessments must focus on dutiable imports. Even here, if the MFN rate is negligible-below 2 or 3 percent - it may not be worth incurring the administrative costs of complying with rules of origin and other requirements (see below).

Empirical analysis of the effects of preferences is confounded by the difficulty of identifying the specific impact of preferences as opposed to other factors. Clearly the observed growth rate of exports from recipients to the countries granting trade preferences is not informative without controlling for other factors. A common approach has been to use (i) simulation methods to estimate trade creation/diversion-which are sensitive to assumptions regarding elasticities — or (ii) gravity regressions where preference status is captured by a dummy variable. However, most studies have severe shortcomings as they fail to take into account that (a) preference rules are often determined at the very disaggregated product level, (b) the elasticity estimates at this level of aggregation are generally absent, and (c) finding the right controls to include in regressions are difficult. These data and methodological problems help explain why the policy-oriented literature has tended to rely heavily on descriptive indicators. Four indicators are particularly common: (i) calculation of preference margins - the difference between MFN and preferential tariffs for products; (ii) potential coverage - the ratio between products covered by a scheme and the dutiable imports originating in beneficiary countries; (iii) utilization: the ratio between imports that actually receive preferential treatment and those that are in principle covered, a measure of how effectively 
beneficiaries are able to use preferences; and (iv) utility: the ratio of the value of imports that get preferences to all dutiable imports from that exporter.

The first empirical analyses of preference schemes appeared in the early 1970s. Looking at the pre-GSP trade flows, Cooper (1972) concluded that "the European scheme ... will offer little help in furthering the economic objectives of developing countries." He points out that the "preference scheme is most generous for those products in which the developing countries are least competitive... In contrast, it offers little incentive, or none at all, to expand exports of those products which are currently of greatest interest to the developing countries, for such export must pay, or expect soon to pay, the full tariff duty" (p. 381). Murray (1973) is also pessimistic about the eventual impact of the preferences. He points out that "only $4 \%$ of beneficiary trade qualifies for preferential treatment under an implemented scheme" and that this only would double when the US implements her program (the US only did so in 1976). He emphasizes that this is due to both free trade on most raw materials exported by developing countries and the exclusion of other products of export-interest to LDCs such as apparel. Murray also notes that there is almost always a ceiling on the amount of exports that can enter duty-free. The advantages of preferences therefore disappear for the "marginal trade and the program simply amounts to a transfer of revenue amounting to the revenue forgone by the donors." The scheme therefore eliminates "stimulus for investment and expanded exports."

Finger $(1975,1976)$ assesses a complementary preferential trade scheme that predates the GSP and has continued to be applied by both the EU and US as part of their customs regimes: outward processing (EU) or offshore assembly (US). Under such customs regimes goods that originate in the EU or US are shipped abroad for processing and pay only tariffs on the value added by the processing when re-imported. The offshore assembly program (OAP) was quite relevant at the time because the US had not implemented a GSP scheme as of the early 1970s. Finger estimates that coverage of "real" i.e., net or additional trade (value added) under the OAP was greater than for EEC GSP — which had entered into force in 1971. A problem with the latter was the associated quota limits (as also pointed out by Cooper and Murray). Finger speculated that EEC OAP could be more effective and see greater trade expansion than GSP In fact, 
in the period after 1989, this was certainly the case for the Central and Eastern European countries and the so-called outward processing trade became a major engine for trade expansion and integration of these economies into the EU. ${ }^{14}$ In effect the OAP was analogous to preferences with restrictive rules of origin as duty free treatment applied only if the inputs were sourced from the US. Finger notes that because of this de facto origin requirement, the OAP created a strong local (US) lobby in its favor-a prescient observation that helps to explain restrictive rules of origin.

The next set of empirical papers included in this volume appeared several years after GSP had been implemented, so that there was enough data to evaluate it. These papers ask if they expand exports from beneficiary countries and at what cost to the donor country (in welfare terms). The methodology used is essentially a Vinerian one that revolves around estimating trade creation and diversion effects of discrimination. Baldwin and Murray (1977) conclude that trade creation is greater than diversion, but that the trade expansion effects of GSP was limited by product exclusions and quantity (quota) ceilings. They then analyze the impact of MFN liberalization on the preferencereceiving countries. This so-called preference erosion issue, currently very topical, has been a central part of the debate on preferences from the very beginning. They argue that developing countries stand to gain from MFN liberalization on the basis of a hypothetical (simulation) scenario of a 50\% cut in all MFN tariffs. Using a partial equilibrium framework, they find that the losses due to preference erosion are more than compensated by the liberalization in products excluded from preferences, suggesting that the interests of developing countries are better served through multilateral MFN liberalization. A natural question then is why developing countries expressed concern over MFN liberalization at the time. This question is also a mainstay of the preferences debate, one that recurs again and again (see below). ${ }^{15}$

\footnotetext{
${ }^{14}$ See e.g., Hoekman and Djankov (1997) for an empirical assessment and references to the literature.

${ }^{15}$ Karsenty and Laird (1987) adopt a similar methodology as Baldwin and Murray, using more disaggregated data and a longer time series. They find that the impact of GSP is much smaller, only $2.4 \%$ of developing country exports, as opposed to $25 \%$ of eligible exports predicted by Baldwin and Murray. The Baldwin and Murray (1977) paper highlights the importance of having good estimates of the relevant elasticities of substitution between foreign and domestic goods and between foreign products of different origin, as the magnitude of their estimated effects were of course sensitive to the parameters used. They assumed - in the absence of information to the contrary - that these elasticities were identical. General equilibrium studies by contrast tend to use Armington elasticities.
} 
One of the first papers to econometrically estimate effects of preferences was Sapir (1981). He uses a bilateral gravity model of the trade flows between the EEC and the developing countries, and obtains results that are similar to those of Baldwin and Murray.$^{16}$ The first estimation is over total trade volume. The GSP-coefficient is positive and significant in only two out of the eight years where the GSP was implemented. In a second sector-specific estimation, the GSP coefficient is significant in 14 out of the 24 possible cases. Although Sapir interprets these findings as evidence in favor of preferences, the results are not particularly robust. Sapir warns that the group of beneficiary countries selected for the exercise is biased in favor of the larger ones.

Furthermore, his analysis indicates that increases in bilateral trade might due to diversion of beneficiaries' exports from other markets into the EEC and does not show that overall exports of the beneficiary countries actually increased.

In a follow-up paper, Sapir and Lundberg (1984) analyze US preferences. They discuss the institutional background of the US GSP regime in detail, and highlight how product and country coverage, rules of origin requirements and quantitative limits on eligible products limit GSP benefits. They find that the trade creation effect of preferences is around $15 \%$ of the imports from eligible countries, and that the benefits are concentrated among certain products and beneficiary countries. They also find that the magnitude of the preference margin by product/country and the (initial) supply capacity of a country are both statistically significant determinants of a positive export impact. These conclusions are echoed again and again in recent policy discussions, and help explain why benefits of preferences have consistently been found to be highly concentrated among a relatively small group of economies.

On the basis of their analysis, Sapir and Lundberg recommend that product coverage should made as wide as possible, that quantitative limits and competitive need restrictions be removed, and that graduation be based on overall economic development rather than performance in a specific export sector. These are all suggestions that continue to be made to this day, and that, to some extent, were gradually incorporated into some of the most recent preference regimes for the poorest countries. Note that an

\footnotetext{
${ }^{16}$ One advantage of the ex post gravity approach is that it will also (implicitly) capture the general equilibrium effects of the preferences, i.e., second-order on other goods and on factor markets.
} 
expansion of the coverage of preferences is also a (temporary) mechanism to attenuate preference erosion due to MFN liberalization. This response to preference erosion is one that also continues to resonate today - many developing countries insist on compensation for preference erosion within the trading system, as opposed to additional aid or assistance to expand supply side capacity. ${ }^{17}$ However, as MFN rates converge towards zero, the scope for maintaining preference margins is becoming ever more difficult.

Brown (1987) was the first to provide results based on a numerical general equilibrium analysis, in contrast to the previous studies which employed partial equilibrium analysis. A general equilibrium framework is superior to a partial equilibrium approach as it allows for possible terms of trade effects, which are critical for any assessment of the welfare impact of preferences. If preferential opening up has a negative effect on the donor's terms of trade it may reduce welfare. Brown (1987) uses a general equilibrium trade model under two different assumptions regarding substitution between domestic and foreign goods. One assumes each good can be produced in any of the countries, the other assumes each country exports a single differential product (i.e., goods are differentiated on the basis of their origin). This assumption implies that even small countries have a certain degree of market power. ${ }^{18}$

Brown's findings are quite different from those found by Baldwin and Murray or Sapir and other authors that had used partial equilibrium models. Her results show that the overall trade diversion effect is larger than the creation effect, implying welfare loss for the United States. Again, benefits are highly concentrated among a small number of higher-income developing countries, while Canada, Japan and Germany appear to be the most adversely affected by the associated trade diversion. In a subsequent analysis, Brown (1989a) applies computational general equilibrium techniques to analyze European preferences. Again she finds that the trade creation effect is much smaller than

\footnotetext{
${ }^{17}$ Another early analysis that assess the impact of preferences by comparing the export revenues of beneficiary countries with an estimate of the counterfactual revenues they might have had without preferences is Aitken and Obutelewicz (1976). They use a gravity model with a dummy variable for preference-eligibility, and conclude that in the 1960s African countries exported about 25 percent more than they would otherwise have.

${ }^{18}$ Brown's work helped also to increase awareness of the importance of the magnitude of the assumed elasticity of substitution between domestic and foreign goods in simulations of the impact of trade policy changes - the lower the elasticity, the greater the implied market power for a small (preferred) country, and the smaller the positive impact on welfare of trade liberalization.
} 
that obtained from previous research, but, in this case, is larger than the trade diversion effect. Nevertheless, there are welfare losses for the donor countries. Benefits are again highly concentrated among a few developing countries. ${ }^{19}$

The impact of preferences is obviously affected by the product coverage and the various limitations and constraints that are imposed by the various national schemes. Clark and Zarilli [1992] note that such limits may go beyond what is formally embodied in the programs in terms of conditionality and graduation criteria. They show that preference-granting countries have used non-tariff trade policy instruments to limit access to the market, thus nullifying or reducing the benefits of preferential access. Devault (1996) estimates the impact of one specific limitation that is often found in preference programs: competitive need limits. These are quantitative limits (upper bounds) imposed on successful exporters under GSP. Once these quotas have been exceeded, the preferences are withdrawn (see above). Devault finds that the limits that apply in the US program reduce potential exports by $10-17$ percent, and that the main beneficiaries of these restrictions are not competing exporters in the rest of the world but the US importcompeting firms.

Nontariff barriers (NTBs) and competitive need limits are a reflection of the political economy realities that determine trade policies in all countries. Clearly, the more competitive are the preference receiving countries, and the greater their capacity to sell into the import market is, the more resistance there will be from import-competing industries in the donor country. Such interests have been able to employ various mechanisms to control the volume (value) of preferred imports - as reflected in the various provisions described earlier when summarizing the main features of preference schemes. Analysis has centered more on other issues: the (possibly unintended) costs of associated with administration of preference schemes - which restrict their value to recipients; and the political economy of preferences, including their relationship to development aid, the distribution of associated rents, and the impacts of preferences on the trade policies of donor and beneficiary countries.

\footnotetext{
${ }^{19}$ Using the same model, Brown (1989b) finds that the Japanese GSP is strongly trade creating, because preferential treatment is offered primarily on products for which Japan is a major world exporter. Here also tariff concessions result in a deterioration in Japan's terms of trade, which lowers welfare in Japan and improves the welfare of Japan's major trading partners.
} 
Most of the research has for obvious reasons focused on the effects and the potential for preferential access to OECD markets. As developing countries have increased their per capita incomes at very different rates since the 1960s, some have become substantially better off than others. As a result, there is great potential for socalled South-South trade, and proposals have been made for more advanced developing countries to grant preferences to the poorest countries. Erzan, Laird and Yeats (1988) analyze the formal (UN) proposal to establish a Global System of Trade Preferences (GSTP) among developing countries. Using a partial equilibrium framework, they simulate the potential increase in South-South trade that could result from implementation of a GSTP. They conclude that full tariff preferences (i.e., 100 percent margins) could increase South-South trade by about 17 percent. As always, results are sensitive to choice of elasticities.

\section{The utilization of preferences}

Rules of origin need to be a part of preference programs to prevent trade deflection. Any such rules give rise to enforcement costs, but they may also be captured by importcompeting lobbies seeking to make them prohibitively costly. A seminal paper on rules of origin is Herin (1986), the first to quantify the costs associated with them. Herin analyzed trade between EFTA members and the EEC - trade flows that in principle should have been duty free due to a trade agreement, and found that one-quarter of flows paid the applicable MFN duty rather than claim duty free treatment. He concluded that the rules of origin were equivalent to an import tariff between 3 and 5 percent. Subsequent work, much of it quite recent, comes to very similar conclusions in terms of the tariff equivalent of rules of origin. Given that MFN tariffs have fallen over time, this further reduces the effective value of tariff preferences. ${ }^{20}$

\footnotetext{
${ }^{20}$ Brenton (2003), Brenton and Manchin (2002), Cadot et al (2003), Inama (2003), and Anson et al. (2004). Brenton and Manchin (2002) found that only 35\% of CEECs' exports enter the EU using the lowest tariff for which they would be eligible. Inama (2003) finds that almost two-thirds of imports by the Quad from GSP beneficiaries entered under a preference scheme, but that only two-fifths benefited from a preference. GSP utilization rates for preferences granted by Canada, the European Union, Japan, and the U.S. are 61, 31, 46, and 67, percent respectively (WTO, WT/COMTD/LDC/W/31), September 29, 2003). Brenton and Ikezuki [2004] conclude that the utilization of ACP preferences is quite high (over 80\%) for most countries but that this measure is upward biased - it does not take into account that for many processed agricultural and manufactured products the rules of origin are prohibitive (i.e., the beneficiary LDCs cannot export without preferences and the rules of origin are strict enough to prevent the use of preferences).
} 
Rules of origin also have more indirect effects. They make it more difficult to achieve economies of scale, since input requirements may vary according to destination markets of the final products. They also generate an incentive to import components and intermediate inputs from the preference-granting country, potentially giving rise to economic inefficiency and (additional) trade diversion (Brenton and Manchin, 2002). Brenton (2003) provides a survey of these various effects and the recent literature. He recognizes that the low utilization of EBA is due to use of ACP preferences and therefore places weight on the utilization rates for non-ACP beneficiaries. He concludes non-ACP countries are not using EBA partly due to fact that the rules of origin are less favorable than under Cotonou. This finding puts into perspective the additional contribution that the EU initiative implied and suggests that the "down payment" implied for the Doha round was rather small in total, and did virtually nothing for most of the LDCs. ${ }^{21}$ The conclusion emerging from recent research (Anson, et al, 2004; Carrère and de Melo 2004 and Cadot et al. 2004) is that even in the context of reciprocal free trade agreements, developing countries get little effective market access since rules of origin are stricter for goods where the preference margins are the greatest (see also Hoekman, Ng, and Olarreaga, 2002).

Candau, Fontagne and Jean (2004) find that underutilization matters most in textile and garments (for imports into the EU under both GSP and EBA programs). In the case of EBA exporters in principle benefit from $100 \%$ duty-free access, but are found to pay up to $6.5 \%$ average tariffs. While Candau et al. conclude that overall much of the existing research overstates the extent of underutilization of preferences, they also find that the utilization of preferences is lower when the preferential margin is small, indicating that compliance costs (such as rules of origin) are a factor.

Stevens and Kennan (2004) summarize a recent investigation of the effectiveness of trade preferences. They conclude that utilization of preferences is high-e.g., only $2.4 \%$ of African exports to the EU that were eligible for ACP preferences (and were not duty free under MFN) failed to use the preferences. They also found that EU preferences have had limited benefits overall, but that there has been a significant positive impact on

\footnotetext{
${ }^{21}$ Mattoo, Roy and Subramanian (2002) come to the same conclusion in the case of AGOA. The latter provides a real world example of the impact of rules of origin as the rules were relaxed for a subset of very poor countries for a limited period. Exports from these countries boomed.
} 
a relatively small number of African states that are able to export preferred products. The US African Growth and Opportunity Act (AGOA) was found to have had a major impact in boosting clothing exports, especially from countries that benefited from liberal rules of origin. Stevens and Kennan conclude that a principal reason for limited benefits of preferences is the inability of many countries to produce goods competitively, and not the functioning of preference regimes. This suggests the main need is for further action on the supply side to facilitate diversification (into preferred goods) by a larger number of countries and to assist countries to meet increasingly onerous sanitary and phytosanitary (SPS) standards. That is, the solution to greater integration of the poorest countries into the trading system extends beyond preferences into the domain of aid and domestic policies, a conclusion to which we return below. But they also concur with the conclusions of other authors that rules of origin are an important barrier to using preferences, and that there is a need for simplification and harmonization of rules of origin.

\section{Development Objectives and Political Economy}

A major feature of preferences is that they (are supposed to) result in a resource transfer. This transfer is implicit, but measurable. If recipients are able to get higher prices for their exports in a protected market, they earn certain rents. These imply a real resource transfer from consumers in that preference-granting market to the exporters that benefit from preferences. Obvious questions are (i) how large the rents are, (ii) who gets them and (iii) whether this is an (politically) efficient way to transfer the associated resources. Of course, one can argue that there is more to preferences than rents, as the idea is to promote industrialization and that can (should) give rise to positive spillover effects and possibly dynamic gains for recipients. The extent to which this occurs is an important question for research. The preponderance of the available evidence in this regard is that preferences, if effective (i.e., used and of value), have done more to generate rents and rent transfers than they have done to foster industrial development (Page and Kleen, 2004). However, in terms of what would now be called "aid effectiveness", it is important to determine whether preferences - because they are tied to trade, and thus may have a variety of spillover benefits in addition to resource transfers-dominate aid. The 
issue of transfer efficiency is also important, especially in light of possible political economy resistance to direct financial transfers to developing countries. ${ }^{22}$

Johnson (1967) was among the first to discuss some of these issues. An early formal analysis is McCulloch and Pinera (1977). Assuming a political equilibrium in a preference granting country that has determined the external level of protection, they assume there is a shift in social preferences that gives higher weight to development abroad. There is then a choice to be made between trade (preferences) and aid. The former will upset the initial trade policy equilibrium. Preferences have a number of effects in their model - they may enhance consumer welfare both because they care about development and because the preferences entail partial liberalization and may lower import costs. But they come at a cost to the initial social objective that underpinned protection in the first place, which helps explain why preferences are in practice often "modulated". While the political economy issues are exogenous in their model, this paper formalizes some of the issues also discussed by Johnson [1967] on the tradeoffs and linkages between preferential trade and aid. ${ }^{23}$

Ray [1987] provides an empirical assessment of the hypothesis that political economy forces play an important role in shaping the extent of effective market access granted under GSP schemes. He shows that special interests were able in the US to limit the ability of "preferred" suppliers to contest the most protected market segments—which are protected by other instruments in addition to tariffs, including NTBs. The Caribbean Basin Economic Recovery Act (CBERA) is a good example of the prevalence and impact of such political constraints. When enacted, only about one-fourth of the exports of CBERA countries were subject to duty; ${ }^{24}$ Ten years later, just 19 percent of the region's exports to the United States entered duty-free under the CBERA, and only 10.1 percent would not otherwise have been eligible for duty-free treatment under the GSP or the US off-shore assembly program (see above). If account is taken of product coverage restrictions, CBERA benefits implied a net reduction in applicable tariffs of some 40

\footnotetext{
${ }^{22}$ For example, Borrell (2004) argues that for every dollar of benefit that the EU banana policy brought to producers in ACP countries, the regime harmed non-ACP developing country producers by almost exactly one dollar - and in the process harmed EU consumers by more than US\$13. Aksoy and Beghin (2003) report that every dollar equivalent transferred to recipients under US preferences costs US $\$ 5$.

${ }^{23}$ See Adam and O'Connell (2004) for a more recent analysis of this question.

${ }^{24}$ What follows draws on OECD (1997).
} 
percent, and not free access for protected goods. As of the mid 1990s, the average tariff paid by Caribbean basin exports to the United States was higher than it was before CBERA was enacted (OECD, 1997). Limited export expansion also reflected quotas and other NTBs, especially for products such as sugar and textiles and clothing. Not surprisingly, benefits are concentrated in highly protected agricultural products (tobacco, sugar, and beef) and in products assembled from US components for export to the US (electronic equipment). ${ }^{25}$

In much of the research on preferences it is generally implicitly assumed that the difference between domestic prices prevailing in the protected market granting preferential access and the world price (the amount of tariff revenue avoided by preferred exporters) accrues to (is captured by) the exporting firms (country). It is not clear that this will necessarily be the case. After all, importers will know that the price wedge exists, and, if they have some market power, it is likely that they will reduce the prices offered to suppliers in the preference receiving countries and capture some of the difference themselves. Thus, in practice some of the rents created by preferences - if any-will be captured by importers and/or distributors. Olarreaga and Ozden (2004) investigate this issue in the case of garment exports from AGOA beneficiaries to the US and conclude that two-thirds of the rents created by AGOA may actually go to U.S. importers. Stevens and Kennan (2004) also conclude that the important role of US buyers and their ability to choose the country from which to import suggests that they will be able to appropriate some of the rents. They note that part of the rents stay with the beneficiaries, and that this adds to the gains, i.e., come on top of the additional volume of exports (and production/employment) generated by the preferences. In practice, much will depend on how a preference scheme works, in particular whether there are quotas allocated and the characteristics of the products (market structure, substitutability, etc.). Page and Kleen (2004) argue that the EU sugar quotas, by assigning specific quotas to countries, probably ensure that much of the rent will go to the recipient countries. ${ }^{26}$

\footnotetext{
${ }^{25}$ Rousslang and Lindsey (1984), Pelzman and Schoepfle (1988) and Sawyer and Sprinkle (1990) provide empirical estimated of the likely impact of CBERA.

${ }^{26}$ Özden and Sharma (2004) found that the price increase associated with preferential access to the US for Caribbean exports was much less than the difference between world and US domestic prices. They conclude that CBI exporters get two-thirds of preference margin, and that this has been eroded by NAFTA and will erode further post ATC implementation.
} 


\section{Political Economy Effects in Recipient Countries}

The likelihood of an importing country removing trade preferences is highly correlated with the growth rate of the exports of the beneficiary country (Ozden and Reinhardt (2003). In other words, countries are likely to be excluded when they start to export 'too much'-i.e., once they actually start to benefit from GSP programs. Ozden and Reinhardt (2003) compare the export performances of US GSP beneficiaries with those of countries that were removed from eligibility ('graduated'). Their results suggest that countries that were removed from the GSP outperform those remaining eligible for GSP treatment. Graduates tend to have higher export/GDP and industrial exports/GDP ratios, as well as higher growth rates. They hypothesize that this finding may be due to graduating countries undertaking own reforms and making more market access concessions themselves. ${ }^{27}$

In a follow up paper, Ozden and Reinhardt (2005), they explore whether there is any evidence that there is a causal relationship between preferences and a more protectionist trade policy stance in recipient countries. They find that US GSP recipients implement more protectionist trade policies compared to countries removed from the GSP program. They note that preferences can decrease the incentives for domestic exporters to mobilize in favor of more liberal trade policies. Since own trade policies are more important for developing countries' growth prospects than barriers in export markets, this perverse incentive effect of unilateral preferences may be quite damaging.

This line of argument has not gone unchallenged. It can be argued that if a (transitional) SDT regime is required to help developing countries to successfully liberalize their economies, Ozden and Reinhardt may be finding evidence that preference programs are working as intended (or designed). Clearly for some countries - the successful ones that were "graduated"-GSP may have played a role in generating the initial export expansion and then breaking a domestic political deadlock that precluded opening up the economy. Major exporters such as Hong Kong, Taiwan, South Korea and

\footnotetext{
${ }^{27}$ The potential detrimental incentive effects of preferences on recipient's own trade policies were noted by Hudec (1987).
} 
Singapore all benefited from US and EU preferences in the 1970s, and subsequently to being removed from eligibility continued to do very well on the export front.

Conconi and Perroni (2004) develop a theoretical framework that provides an economic rationale for what is observed by Ozden and Reinhardt. They argue that preferences are premised on inter-temporal reciprocity, and that the fact that recipients lower their trade barriers once they have graduated from GSP may simply reflect a temporal lag between reciprocal concessions, rather than GSP graduation directly inducing countries to liberalize. The stylized facts that motivate the Conconi and Perroni analysis are the following: LDCs get deeper preferences than other developing countries; as (very) small price takers LDCs should in principle pursue unilateral liberalization, but do not; and preferences are granted on an explicitly temporary basis. These stylized facts are argued to indicate that the (political) constraints on trade liberalization faced by LDC governments are viewed by all parties as transitory, and that the apparent gap between short-run protection incentives (because of lobbying) and long-run liberalization incentives reflects a time consistency problem for LDC governments. This commitment problem can then explain both the scope for SDT-based trade cooperation with the large developed country, and the temporary nature of SDT. Given the commitment problem (and also assuming there are adjustment costs), a self-enforcing dynamic agreement is argued to necessarily feature higher protection in the small country in comparison with long-run equilibrium tariff (i.e. delayed implementation); and, lower protection by the large country (i.e. temporary GSP concessions). Thus, their model rationalizes temporary SDT as a transitional cooperative regime between a (small) developing country and a large, high income economy. The concessions are reciprocal but non-simultaneous, and are linked, explicitly or implicitly, by conditionality, given that cooperative trade policy outcomes must be self-enforcing. ${ }^{28}$

\footnotetext{
${ }^{28}$ As noted above, explicit conditionality is often part and parcel of GSP programs. For example, the US in AGOA conditions preferences on actions by recipients to eliminate "barriers to US trade and investment". An October 20, 2004 EU proposal for a new, simplified GSP regime would make preferences conditional of recipients signing 27 international treaties, including 16 ILO conventions, three dealing with drugs and 7 pertaining to the environment.
} 


\section{Summing up: Preferences-the good, the bad and the ugly}

The bottom line is that the research suggests that preferences are widely used by many countries, but that the benefits are reduced by a variety of factors, whether by design, incidentally, or by domestic supply constraints. Much depends on how binding rules of origin are and how high are MFN tariffs. A recent analysis suggests that if one assumes away preferences - i.e., only MFN barriers are assumed to apply - developing countries would confront higher protection in the OECD than other countries, i.e., the current structure of protection implies a negative preference margin. This is illustrated by the darker bars in Figure 1, which reports an overall trade restrictiveness index (OTRI). ${ }^{29}$ Alternatively, if it is assumed preferences are fully utilized - that is, we assume away rules of origin and other constraints, which are known in practice to reduce the utilization of preferences, and it is assumed that all rents created by preferences accrue to exporters - there is still much to be done to remove the negative effect of trade barriers.

Figure 1. OECD Protection and Preferences

口Full utilization $\square$ No utilization

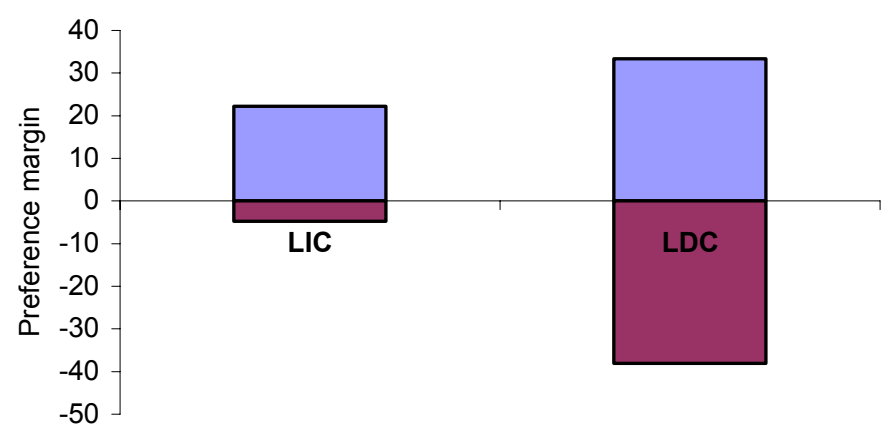

Source: IMF and World Bank, 2004.

The average reduction in OECD trade barriers due to the preference programs is not more than 20-30 percent of MFN rates (IMF and World Bank, 2004). In part this is due to (i) the effect of NTBs that apply to all imports, (ii) the fact that OECD countries

\footnotetext{
${ }^{29}$ What follows draws on Hoekman (2004a). The OTRI is the uniform tariff equivalent of all the trade policies (tariffs and core NTBs) maintained by a country that would replicate the observed volume of imports. It includes estimates of the ad valorem equivalents of specific tariffs, core NTBs, and agricultural producer subsidies. See Kee, Nicita and Olarreaga (2004) for details.
} 
often trade on a duty-free basis as a result of PTAs and (iii) the incomplete coverage of non-reciprocal preference programs (product exceptions, etc.). If, more realistically, it is assumed that utilization rates are only 50 percent, the OTRI against LDCs is roughly the same as that applying to all trade: around 6 percent.

A key question in assessing the effect of preferences is whether they help create industries that are viable-i.e., can survive the removal of preferences, either as the result of unilateral actions or MFN liberalization (such as tariff reductions or the abolition of the final ATC quotas at the end of 2004). If they do, the preferences have helped nurture infant export industries and achieved their goal. If they do not, they provide only a temporary increase in income, 'rents' from the higher price attainable in the protected market. This resource transfer can be significant, as is the case for sugar and bananas, , for some countries (Mauritius, the Caribbean). For such commodities and beneficiary countries the only benefit is the increase in income. Even if they do, one must ask at what cost to donors, to recipients and the rest of the world. Clearly in some cases preferences have helped to generate transfer of skills and know how-e.g., in the case of AGOA for apparel exports from Lesotho. Page and Kleen (2004) argue that some of the exporters 'created' by the MFA or more recently by AGOA, such as Bangladesh, Mauritius, and perhaps Lesotho, will have higher exports than they would have done without their period of high preferences due to the ATC, even when this "preference" is eliminated.

Are preferences good for development? It is probably fair to say that the jury is still out, in that there is no consensus in the literature. However, the majority view seems to be that they are at best a marginal benefit. There is a consensus that they are certainly not sufficient. Their value as a development tool has been limited for all the reasons that have been identified in the literature. If effective in increasing recipients national income, this comes at a cost to other developing countries through trade diversion and the inherent discrimination associated with preferences. Also, if effective in transferring resources, one can question the cost effectiveness both in terms of costs to consumers/taxpayers in donor countries and the costs associated with the various side conditions, uncertainty, etc. Much also depends on how the associated rents and additional income are distributed within the recipient countries and how it is used. If not used to improve the investment climate and foster diversification, preferences may have perverse effect of inducing 
countries to remain specialized in low value commodity production and other sectors in which they do not have comparative advantage. Finally, it should be kept in mind that preferences imply discrimination and thus trade diversion and red tape. The most successful examples of countries that used trade as a core part of their growth strategy in the last 30-40 years - the period of preferences - did not rely on them for their export success.

\section{From Uruguay to Doha and Beyond}

The second major plank of SDT in the trading system concerns the reach of WTO rules and technical assistance. A precondition for developing countries to benefit from WTO membership is "getting the rules right" from a development perspective. Most developing countries are late-comers to the multilateral trading system - a fact that helps explain why many present WTO rules predominantly reflect the interests of rich countries and the status quo disciplines that already have been put in place by them. Thus, the much greater latitude that exists in the WTO for the use of agricultural subsidization, for example, reflects the use of such support policies in many developed countries. The same is true for the permissive approach that has historically been taken toward the use of import quotas on textile products - in principle prohibited by GATT rules. More recently, the inclusion of rules on the protection of intellectual property rights has strengthened perceptions that the WTO contract is unbalanced.

Rather than use a case-by-case approach based on economic analysis to determine the development costs and benefits of specific proposals or rules, the WTO has relied primarily on a mix of temporary and permanent exceptions for developing countries, with temporary exemptions taking the form of (uniform) transition periods for two broad categories of countries (LDCs and all other developing countries). Thus countries do not have any multilateral "assurance" that rules will only apply once the preconditions are in place to benefit from implementation. This is a function of the extent to which other members perceive it to be in their interest to initiate dispute settlement proceedings and/or their willingness to accord waivers and provide assistance with implementation of resource-intensive disciplines.

It is a basic principle of economics that interventions should directly target the source of a market failure. Trade policy will rarely do so. Even if trade policies are used, 
there is a clear efficiency ranking of instruments, quotas and analogous instruments being particularly costly. WTO rules that impose disciplines on the use of such instruments benefit both consumers and producers and enhance social welfare. Similarly, binding tariffs and abiding by WTO rules and criteria for taking actions against imports that injure domestic industry are beneficial - by reducing investor uncertainty and requiring a determination of the facts underlying a situation. This is not to deny there are second best cases where intervention may be justified, but such cases need to be documented. This is rarely done.

The papers by Hindley (1987) and Wolf (1984), written as countries were gearing up to launch the Uruguay Round, argued that many of the policies that are permitted by the GATT/WTO will be ineffective or inefficient. Both also argue - to use Wolf's termthat SDT is a two-edged sword: it may produce some benefits, but there are costs as well, including the systemic effects of efforts to maintain preference margins. Wolf is critical of the Enabling Clause-including looser disciplines on South-South preferential trade agreements, which he argues can do little to promote development or increase the bargaining power of developing economies. The numerous exceptions and exclusions for developing countries in the GATT will not help governments deal with the political economy factors that keep high-cost protectionist policies in place. More specifically, Hindley notes that a greater focus on differentiation between SDT recipients is needed, implying in turn the need for a more explicit focus on "graduation" in the WTO. ${ }^{30}$

The issues raised in these papers continue to dominate WTO discussions. There is a huge literature on the fundamental question whether the core trade policy rules of the WTO should apply to all countries, developed and developing. Some of this literature is summarized in the Hindley and Wolf papers. ${ }^{31}$ Much of this research went (and goes) against the type of rule-related SDT found in the GATT. It resonated with many GATT members in the Uruguay Round. As discussed in Whalley (1999), a major result was that rather than allow opt-outs, the focus turned to integration of developing countries into the

\footnotetext{
${ }^{30}$ As argued by Michalopoulos (2000), limited country coverage is a political precondition for meaningful preferential treatment for the poorest countries. See also Pangestu (2000). Hart and Dymond (2002) is a recent paper in the vein of Wolf (1984).

${ }^{31}$ For recent assessments of the East Asian experience and the case for trade intervention see Noland and Pack (2003), Srinivasan and Bhagwati (2001) and Panagariya (2003a). McCulloch, Winters and Cirera (2001) survey some of the literature.
} 
system of rules. The presumption (implicit if not always explicit) was that "one size fits all" and that the rules of the game were beneficial to all, and needed to be implemented by all (Finger, 2002). Until the Uruguay Round, many new GATT agreements were implemented on a voluntary basis — only signatory countries were bound by them (Hoekman and Kostecki [2001]). The Single Undertaking removed this practice and required virtually all WTO agreements to apply to all member countries, irrespective of level of development. It was of course recognized that some countries confronted implementation constraints and associated burdens. This was addressed through the use of longer transition periods for developing countries, supplemented by promises of technical assistance, not through opt-outs. The shift was not (just) a reflection of NorthSouth differences - many developing countries also viewed the old type of SDT "as ideological baggage from the past, or described as a crutch which developing countries no longer needed and which was actually hindering their competitiveness" (Gibbs, 1998). The consequence was that in contrast to the GATT, SDT under the WTO became issueor agreement-specific - there was (and is) no overarching conceptual framework to recognize development needs and constraints.

A reason for the change that occurred in the "type" of SDT found in the WTO as compared to GATT was that, during the 1980s, SDT increasingly became perceived as an ineffective instrument. It had not delivered what it was supposed to: greater participation of developing countries (recipients) in the multilateral trading system (Wolf, 1984; Whalley, 1999). Starting in the 1980s, developing countries also began to perceive that the balance of their interests had changed - they were increasingly subject to non-tariff barriers and measures that increased the extent of discrimination against them, offsetting any benefits from preferences. Among these were higher use of voluntary export restraints (VERs), unilateral threats in particular by the US to invoke Section 301 against their alleged "unfair trade practices" (especially in the area of intellectual property protection), an ever expanding web of free trade agreements between developed countries, steady expansion of the product and country coverage of the MFA, and mounting use of contingent protection (especially anti-dumping). Moreover, the so-called Tokyo Round codes (agreements on new issues and extensions of existing GATT disciplines), while not binding developing countries that did not wish to subscribe to 
them, was moving the trading system towards a more clearly defined two-track regime, with the possibility of non-signatories being excluded from the benefits arising under the codes. One consequence was that developing countries saw an interest in strengthening multilateral disciplines. As a result, specific emphasis was put on banning the use of VERs, the abolition of the MFA, the re-insertion of agricultural trade into the GATT, and strengthening the dispute settlement mechanism (the latter very much driven by a desire to discipline the use of Section 301 actions by the US). ${ }^{32}$

Some of the resulting WTO agreements, in particular the Agreement on Traderelated Aspects of Intellectual Property Rights (TRIPs), were highly skewed towards benefiting rich countries. Others generated asymmetric implementation costs because the new rules that were written reflected existing practices in developed countries (Finger, 2002; Weston, 1995). As a result, it is not too much of an exaggeration to speak of an Uruguay Round "hangover" for many developing countries -and a great deal of skepticism regarding the benefits of WTO membership (Hoekman, 2002). Starting in the late 1990s a re-thinking of the Uruguay Round approach began, in parallel with the Doha round talks.

The 2001 Doha Ministerial Declaration emphasized the importance of SDT, stating that "provisions for special and differential treatment are an integral part of the WTO agreements." Paragraph 44 called for a review of SDT provisions with to the aim of "strengthening them and making them more precise, effective and operational." On the basis of this mandate, developing countries made 88 suggestions to strengthen SDT language in various WTO agreements. The proposals included calls for improved preferential access to industrialized countries, further exemptions from specific WTO rules, and binding commitments on developed countries to provide technical assistance to help implement multilateral rules. Despite intensive talks during 2002-03, no agreement on these proposals emerged. One reason was that many of the proposals sought to convert nonbinding, "best endeavors" language into obligations binding on developed countries. Another was disagreement over what types of provisions would promote development. With the collapse of the Cancun Ministerial meetings none of these demands were implemented.

\footnotetext{
${ }^{32}$ See Hoekman and Kostecki (2001) for more discussion and references to the literature.
} 


\section{Moving Forward: Key Challenges}

There are many issues on the table, but two stand out: whether to maintain preferences as a form of aid, and what to do about preference erosion; and whether and how to enhance the "development relevance" of WTO rules.

\section{Preference erosion and MFN-based reforms}

As mentioned, preference erosion is an old concern that was already being analyzed in the 1970s. Until recently the question of erosion was not a particularly strong constraint on MFN-based reforms in the GATT/WTO because GSP programs only gave a preference and not duty/quota free access. Thus, even if MFN rates were lowered, it was possible to maintain a given preference margin (by lowering the preferential tariff and or expanding the coverage of the scheme). New programs such as EBA or AGOA feature duty and quota-free access for (virtually) all products and therefore any reductions in MFN tariffs lower the preference margin. A basic question confronting WTO members now is whether to continue to use trade preferences as a form of aid - which could have the effect of precluding a move to very low or zero MFN tariffs.

An early analysis and potential response to the preference erosion "constraint" was suggested by Ahmad (1977), who proposed limiting the impacts on the preference erosion side through a selective application of MFN liberalization-on goods that developing countries do not produce (yet). Ahmad argues that "there is little doubt that in the long run the problem of the industrializing Third World is one of securing unlimited access to world markets through across-the-board tariff reductions. In the meantime, however, the continuation of preferential margins ... has a higher probability of inducing initial investment and productivity in developing countries' manufacturing sectors." This is an argument that has continued to be made by those supporting (more effective) preferences, including the suggestion that preference margins be bound in the GATT. ${ }^{33}$

Yamazaki (1996) estimates the value of EU, Japanese and US schemes to beneficiary countries with a view to determining the potential impact of preference

\footnotetext{
${ }^{33}$ As already noted, doing this is very difficult to operationalize if MFN tariffs continue to fall-if considered seriously, it would imply stopping MFN liberalization.
} 
erosion across countries (regions). He concludes that the preferences, on average, equal 12 percent of the total value of eligible exports, three-quarters of which is generated by EU programs. Echoing others in the literature, almost half of the total benefits (by export value) generated by the EU is due to the EU Sugar Protocol. ${ }^{34}$ Yamazaki's conclusions that the impact of preferences are highly concentrated - a recurrent finding in the literature has been well known for decades - also suggests that problems of preference erosion are concentrated.

There are two crucial questions: the potential magnitude of erosion (a key input into any determination of the overall level of financing that may be needed to address it) and the sectoral composition of the potential impacts (a key factor determining the incidence and distribution of adjustment costs within countries). Using a partial equilibrium framework, IMF (2003) examines the overall impact on the exports of LDCs from preference erosion arising from trade liberalization by the Quad. Assuming a 40 percent cut in protection in the Quad and that LDCs have free access to these markets (a strong assumption given the literature cited above), it concludes that the potential loss at the aggregate level amounts to just 1.7 percent of total LDC exports. However, individual LDCs may suffer a more significant loss from preference erosion due the concentration of their exports in products that enjoy deep preferences. Of these, Malawi, Mauritania, Haiti, Cape Verde, and São Tomé and Príncipe are found to be the most vulnerable to preference erosion. Malawi was predicted to experience a loss of $11.5 \%$ of total exports, the next four countries between 5 and $10 \%$, and another 10 countries between $3 \%$ to $5 \%$. The total (aggregate) value of export revenue that would be lost was around \$530 million (of which two-fifths would be accounted for by Bangladesh). Note that these are small numbers - equivalent to only one percent of ODA flows.

Earlier research by Yeats (1995), also using a partial equilibrium framework, estimates that the complete elimination of MFN tariffs by the EU, Japan and the United States would result in total erosion costs for 29 Sub-Saharan African countries of some US\$4.2 billion of exports (in present discounted value terms), with the reductions in exports to the EU and Japan on the order of 1-2 percent, and an increase in exports to the

\footnotetext{
${ }^{34}$ Also significant were preferences for tobacco. As noted by Alexandraki and Lankes (2004), given that Yamazaki's dataset ends in 1992, bananas are not covered as the EU banana regime began in 1993.
} 
US market (of some 4 percent). The latter is driven by the fact that nondiscriminatory liberalization by the US more than offsets any erosion losses. Cameroon, Cote d'Ivoire, Kenya, Senegal and Zimbabwe account for 85 percent of the total predicted loss. Yeats predicts that sub-Saharan Africa will lose more exports through the erosion of preferential treatment than it will gain from MFN trade liberalization. Page and Davenport (1994) come to similar conclusions, with predicted reductions in ACP and LDC exports on the order of 1-2 percent, with Ethiopia (5.9 percent), Malawi (5.3 percent), Guyana (4.8 percent), Mozambique (4.6 percent), and Jamaica (3.2 percent) experiencing larger impacts (OECD, 1997).

The limited number and small size of most of the economies concerned imply that measures to help mitigate the impact of preference erosion should be closely targeted at the countries at risk. The detailed assessment by Alexandraki and Lankes (2004) indicates that many of the countries concerned are not among the poorest, but are middleincome economies. They include sugar, textiles and banana programs in their analysis. Indeed, the IMF analysis and Steven and Kennan (2004) suggest that the potential erosion problem is heavily concentrated in (small island) economies that are dependent on quotatype preferences and the associated rents in these sectors. ${ }^{35}$ The problem is therefore also commodity-specific since they are concentrated in areas where OECD protection and preference margins are the highest. As stressed by Tangermann (2002), insofar as preferences have had the result of "sucking" investment and production into the wrong direction (i.e., areas where they do not have a comparative advantage), the effect has been to make the beneficiaries dependent on preferential exports. As the sugar and banana regimes are reformed in the EU, such countries will be confronted with major adjustment costs.

The solution to this problem is not to maintain (or expand) the existing preferences but to ensure that the countries concerned are assisted. An appropriate response would be for the OECD countries to convert the (implicit) "preference

\footnotetext{
${ }^{35}$ Preference dependent or sensitive countries include Mauritius, Malawi, Mauritania, Cambodia, Maldives, Haiti, Cape Verde, Sao Tome, Tanzania and the Comoros (Stevens and Kennan, 2004). The only large country expected to suffer from preference erosion is Bangladesh, which has benefited significantly from the quota restrictions imposed on other large competitive developing countries such as China. It can be noted that the potential impact on non-quota controlled textile and clothing exporters of removal of quotas has been on the agenda since the negotiation to end the MFA in the Uruguay Round (Page and Davenport 1994).
} 
transfers" into equivalent development assistance, which could be used by the recipient governments to fund adjustment costs. In the case of farmers in beneficiary countries (e.g., sugar, bananas) an option could be to integrate them into OECD farm policies and extend decoupled income-support to them as well as to national farmers. How to implement the needed shift from preferences to aid is likely to become an important part of the Doha agenda. A number of issues would have to be resolved: (i) ensuring that financing commitments are (and are seen to be) credible; (ii) the associated aid is additional to existing flows; and (iii) ensuring that the aid was used to effectively address the adjustment burden in recipient economies. It is important that the financing facility be a temporary one that is limited to dealing with the adjustment costs associated with preference erosion. Insofar as developed countries desire to support the countries concerned on a longer term basis, the appropriate vehicle is aid. ${ }^{36}$

Finally, we should note that in principle, if countries desire to continue using trade as a form of aid, this could be achieved even if all MFN duties are abolished. Limao and Olarreaga (2004) argue that in such a scenario importing countries could simply give beneficiary countries an import subsidy. Their analysis suggests that the conversion of all current tariff preferences into equivalent import subsidies would enhance welfare in both donor and recipient countries.

\section{WTO Rules and Development}

The last set of papers included in this volume address how the WTO might better reflect the development needs of its members. A common theme of these papers is that currently there is not enough differentiation (flexibility) when it comes to WTO disciplines and that more needs to be done to deal with potential losses from preference erosion. Several options have been proposed in the literature to address the problem of differential priorities and capacities across WTO members: ${ }^{37}$

- Acceptance of the principle of "policy space" - implying flexibility for all developing countries as currently (self-) defined in the WTO system whether to

\footnotetext{
${ }^{36}$ For recent discussions of and proposals for an adjustment facility tied to the implementation of a Doha round set of reforms, see Hoekman (2004b), Page and Kleen (2004), and Winters (2004).

${ }^{37}$ See also Oyejide (2002), Fukasaku (2000), Commonwealth Secretariat (2000), Corrales-Leal et al. (2002), Keck and Low (2004) and Melamed (2002).
} 
implement a specific set of (new) rules, as long as this does not impose significant negative (pecuniary) spillovers (Stevens, 2002, 2003).

- A country-specific approach that would make implementation of new rules a function of national priorities. WTO disciplines implying significant resources would be implemented only when this conforms with or supports the attainment of national development strategies. A process of multilateral monitoring and surveillance, with input by international development agencies, would be established to ensure that decisions are subject to scrutiny and debate (Prowse, 2002);

- An agreement-specific approach involving the ex ante setting of specific criteria on an agreement-by-agreement basis to determine whether a country could opt out of applying negotiated disciplines for a limited time period. Criteria could include indicators of administrative capacity, country size and level of development and a link might be made between implementation and the provision of financial and technical assistance (Wang and Winters, 2000; Stevens, 2002; Keck and Low, 2004).

- A simple rule-of-thumb approach that would allow opt-outs for an agreed set of disciplines for all countries satisfying broad threshold criteria such as minimum level of per capita income, institutional capacity or economic scale (Hoekman, Michalopoulos and Winters, 2003). The presumption here is that this would allow the bulk of identified difficulties to be tackled at little or no negotiating cost. Invocation of an opt-out would be voluntary. As countries come to surpass thresholds over time, disciplines automatically would become applicable.

A common element of many proposals is that use is made of economic criteria to determine the applicability of resource-intensive rules. This makes good sense from an economic perspective, but is very controversial in the WTO as greater differentiation among countries is rejected by many developing-country representatives. Currently, whether a rule is enforced is left to individual members (i.e., whether or not to selfdeclare as a developing country) and a mix of unilateral action and bargaining by developed-country members whether to accept this and whether to provide SDT. In practice, small and poor countries are unlikely to be confronted with dispute settlement/enforcement situations, for their markets are too small to induce action. ${ }^{38}$

Country classification inevitably creates tensions among governments as to which countries would be eligible. The advantage of simple criteria along the Hoekman, Michalopoulos and Winters (2004) lines is that it is "clean" - there is no need for additional negotiation. The disadvantage is that criteria will inherently be somewhat

\footnotetext{
${ }^{38}$ At least for developed countries. For other LDCs, often neighboring countries, actions that violate a WTO commitment may have relatively large effects.
} 
arbitrary. The scope for agreeing on a rule-specific or agreement-specific set of criteria has in the past proven feasible - witness the per-capita income threshold in the WTO Subsidies Agreement for the use of export subsidies, the net food importers group defined in the WTO Agreement on Agriculture or the (implicit) group of countries that do not have a pharmaceutical industry that were the focal point of the Doha Round TRIPS/public health debate. Stevens (2003) discusses possible approaches towards agreement-specific criteria to define SDT. The downside here is that poor countries will be confronted with inevitable negotiation costs and the need to allocate scarce human resources to issues that may not be priorities.

A criteria-based approach will not do much to engage governments and stakeholders, or to help them identify better policies or areas where complementary actions/investments are needed. The presumption underlying criteria-based approaches is that SDT is needed as a mechanism to prevent countries from being confronted by disputes for noncompliance and to identify those needing technical assistance. An alternative approach could be to do more to take government objectives and constraints seriously (Prowse, 2002). This might involve a more economically based interaction between WTO members in instances where countries are not in conformity with WTO rules to determine whether policies were having their intended effect and whether more efficient (less trade distorting) instruments might be feasible. ${ }^{39}$ Greater "policy dialogue" and multilateral monitoring of the effects of policies applied by WTO members could both help to increase the (domestic) accountability of governments and the "ownership" of policies and the multilateral rules.

It could also do much to increase the effectiveness of technical assistance. This is probably a critical input into the delivery of such assistance, a topic that attracted much attention post Seattle, and the subject of the paper by Prowse (2002). Greater transparency is critical to prevent capture of policies by interest groups, to make policies contestable and to give both winners and losers a greater voice in policy formation. While

\footnotetext{
${ }^{39}$ As discussed at greater length in Hoekman (2004b), there is an obvious trade-off between reducing the reach of the DSU and strengthening the development relevance of WTO rules and mechanisms by allowing greater policy flexibility for developing countries. The latter have a great deal to lose if the DSU is hollowed out, as one consequence could be that developed countries become less inclined or are given scope to argue that they should not be held accountable for implementation of negotiated disciplines. Thus, such consultative mechanisms should not preclude recourse to dispute settlement by any member.
} 
an approach that is more intensive in "policy dialogue" may seem rather far-reaching given the legal nature of the WTO rules, there are already numerous mechanisms in the WTO that can be - and at times are - used to engage in policy dialogue. These include the committees that oversee the operation of specific agreements and the Trade Policy Review Mechanism. One committee that explicitly includes a multilateral process of assessment of the prevailing economic situation in countries as a justification for the use of trade restrictions is the Balance of Payments Committee. This operates with inputs from the IMF on the balance-of-payments situation in a member that invokes the relevant GATT articles as cover for trade barriers. In practice deliberations have mostly been "cooperative", with only very cases of recourse being made to the DSU (Prowse, 2002).

\section{Conclusion: Looking Ahead}

The integration of developing countries into the global economy, especially through increased international trade, is a commonly cited and shared objective. One of the dominant paradigms of the last 40 years, special and differential treatment (SDT) for developing countries in the GATT/WTO, does not seem to have delivered what was intended from it. There is a large literature on the reasons for this failure, some of which has been discussed above. The early debates and arguments that pointed to the potential downsides of SDT proved quite prescient - benefits have been limited, skewed in their distribution, and arguably obtained at high cost to the trading system, donor country consumers and many of the purported beneficiaries. Research has demonstrated that preferences can at best play a marginal role to assist developing countries - what determines and drives performance is not what others do, but what countries do for themselves. The latter is also a primary determinant of the effect of preferences, conditional on the extent to which donor countries do not limit the magnitude of the potential benefit through exceptions, limitations, rules of origin, etc. Whether and to what extent preferences and traditional SDT actually hurt countries with weak administrative capacity and institutions (governance) remains a matter for debate.

Whatever the view one takes away from the experience with SDT and preference programs, a good case exists for revisiting the decision to use trade (preferences) as aid (Panagariya, 2003b). Duty-free access for the products of all developing countries 
dominates discriminatory treatment of only a subset (Hoekman, Michalopoulos and Winters, 2004). Moving in this direction implies the erosion of all preferences, both GSP and the deeper, more recent preferences. Even if this does not happen - and realism suggests it will not-further MFN-based Doha Round reforms could have a substantial impact on some countries, especially those with high concentrations of exports in highly protected commodities. The answer is not to avoid liberalization of the sectors where preferences matter most, in the process maintaining a complex system of managed trade in the key sectors where significant rents exist. What is needed is to move toward adoption of transparent, nondiscriminatory trade policies, as initially envisaged by the founders of the GATT. This will imply costs for some countries, which in turn requires credible commitments on the part of industrialized countries to assist during the transition to address adjustment costs, and to shift toward the use of development assistance to realize longer-term resource transfers to poor countries. An expansion in development assistance would constitute both a more efficient and more effective instrument than preferences- as long as these resources are allocated to priority projects through a national development or poverty reduction strategy and used effectively. Given the history of preference programs, developed countries as a group should arguably shoulder this burden: they instituted and preserved the system of discretionary preferences, and they also have the largest interests in the trading system (Page and Kleen, 2004; Hoekman, 2004b). 


\section{References}

Note: references to papers included in the volume of readings are listed in the Annex below.

Adam, Christopher and Steven O'Connell. 2004 "Aid Versus Trade Revisited" The Economic Journal 114: 150-73.

Aitken, N. D., and R. S. Obutelewicz, 1976, “A Cross-Sectional Study of EEC Trade with the Association of African Countries," The Review of Economics and Statistics (Cambridge, MA: MIT Press).

Alexandraki, Katerina and Hans Peter Lankes (2004) Estimating the Impact of Preference Erosion on Middle-Income Countries, IMF Working Paper, Washington, DC: IMF.

Anderson, K. and B. Hoekman. Eds. Forthcoming. The WTO's Core Rules and Principles. Elgar.

Anson, J., O. Cadot, A. Estevadeordal, J. de Melo, A. Suwa-Eisenmann and B. Tumurchudur (2003) "Assessing the Costs of Rules of Origin in North-South PTAs with an Application to NAFTA", CEPR Discussion Paper 2476.

Bhagwati, Jagdish. Editor. 1977. The New International Economic Order. Cambridge: MIT Press.

Borrell, Brent. 2004. "The EU Banana Drama: Not Over Yet," Center for International Economics, Australia.

Bown, Chad. Ed. Forthcoming. The WTO and Temporary Protection for Imports. Elgar.

Brenton, Paul. [2003]. "Integrating the Least Developed Countries into the World Trading System: The Current Impact of EU Preferences under Everything But Arms," Journal of World Trade, June, Vol. 37, no. 3; p. 623-46.

Brenton, Paul and Hiroshi Imagawa (2003) 'Rules of Origin, Trade, and Customs' in de Wulf, Luc and Jose Sokol (eds) (2004) Customs Modernization Handbook, Washington, DC: World Bank.

Brenton, P and T. Ikezuki (2004) 'The Impact of Agricultural Trade Preferences, with Particular Attention to the Least Developed Countries', in M. Ataman Aksoy and John C. Beghin (eds), Global Agricultural Trade and Developing Countries Oxford University Press and the World Bank, Washington D.C., (forthcoming),

Brown, Drusilla. 1988. "Trade Preferences for Developing Countries: A Survey of Results," Journal of Development Studies April.

Brown, Drusilla K. [1989a], "Trade and Welfare Effects of the European Schemes of the Generalized System of Preferences," Economic Development and Cultural Change 37 (July): 757-776.

Brown, Drusilla. 1989b. “A Computational Analysis of Japan's GSP," Journal of Development Economics, 30:103-138.

Candau, Fabien Lionel Fontagne and Sébastien Jean (2004) The utilisation rate of preferences in the EU" CEPII, mimeo.

Carrere, C. and J. de Melo (2004) "Are Rules of Origin Equally Costly? Estimates from NAFTA", paper presented at IDB conference, Washington Feb 2004

Clark, Don. 1998 Are Poorer Developing Countries the Targets of U.S. Protectionist Actions?" Economic Development and Cultural Change, October 1998, pp. 193-207.

Commonwealth Secretariat (2000) Special and Differential Treatment for the Least Developed Countries, WTO Policy Brief No.1, September.

Corden, W. Max. 1979. “The NIEO proposals: A Cool Look," London: Trade Policy Research Centre.

Corrales-Leal, Werner, Mahesh Sugathan and David Primack (2003) "Spaces for Development Policy" Revisiting Special and Differential Treatment, paper prepared for the joint ICTSD - GP international dialogue: Making Special and Differential treatment more 
effective and responsive to development needs, 6-7 May 2003, Chavnnes-de-bogis, Switzerland.

Ethier, W. and A. Hillman (Eds.). Forthcoming. The WTO and the Political Economy of Trade Policy. Elgar.

FAO. 2003. Improving the Value and Effective Utilization of Agricultural Trade Preferences. Rome.

Finger, J. Michael. (1975), 'Tariff Provisions for Offshore Assembly and the Export Earnings of Developing Countries', Economic Journal, 85: 365-71 (June).

Finger, J. Michael. 1976. 'Trade and Domestic effects of the Offshore Assembly Provision in the United States Tariff', American Economic Review, 66(4): 598-611.

Finger, 2002. "The Doha Agenda and Development: a View from the Uruguay Round" (Manila: Asian Development Bank.

Fukasaku, Kiichiro (2000) "Special and Differential Treatment for Developing Countries: does it help those who help themselves," Working Paper No 197, WIDER, The United Nations University.

Gibbs, Murray. 1998. "Special and Differential Treatment in the Context of Globalization," G15 Symposium on Special and Differential Treatment in the WTO Agreements, New Delhi, December 10 (http://www.wto.org/english/tratop e/devel e/sem01 e/sdt e.htm).

Grilli, E. 1997. "EU Trade and Aid Policies Towards the LDCs and CEECs" in Economic Integration Worldwide, Ali M. El-Agra (ed.), London, MacMillan Press: 135-174.

Grossman, Gene, 1982. "Import Competition from Developed and Developing Countries," Review of Economics and Statistics 64: 271-81.

Hart, Michael and Bill Dymond. 2003. "Special and Differential Treatment and the Doha "Development" Round," Journal of World Trade, 37(2) 395-415.

Hoekman, Be4rnard. 2004a. "Dismantling Discrimination Against Developing Countries: Access, Rules and Differential Treatment," CEPR Discussion Paper 4694.

Hoekman, Bernard. 2004b. Operationalizing the Concept of Policy Space in the WTO: Beyond Special and Differential Treatment, World Bank, mimeo.

Hoekman, Bernard and Simeon Djankov. 1997. "Determinants of Export Structure of Countries in Central and Eastern Europe," World Bank Economic Review, 11:471-90.

IMF (2003) "Financing of Losses from Preference Erosion, Note on Issues raised by Developing Countries in the Doha Round," Communication to the WTO from the International Monetary Fund, No WT/TF/COH/14, 14 February.

IMF. 2004. "Fund Support for Trade-Related Balance of Payments Adjustments," http://www.imf.org/external/np/pdr/tim/2004/eng/022704.pdf

Karsenty, Guy and Sam Laird. 1986. The generalized system of preferences : a quantitative assessment of the direct trade effects and of policy options, United Nations Conference on Trade and Development ; no. 18

Karsenty, Guy and Sam Laird. 1987. The GSP, Policy Options and the New Round", Weltwirtschaftliches Archiv, Band 123(2).

Keck, Alexander and Patrick Low (2004) Special and Differential Treatment in the WTO: why, when and how? WTO Staff Working Paper ERSD-2004-03, Geneva: WTO, May.

Kee, Hiau Looi, Alessandro Nicita and Marcelo Olarreaga. 2004. "Import demand elasticities and trade distortions," mimeo, The World Bank, Washington, DC.

Lederman, D., and Ç. Özden, 2004, "United States Trade Preferences: All Are Not Created Equal," World Bank Policy Research Paper, (Washington: The World Bank).

Limao, Nuno and Marcelo Olarreaga. 2004. "David vs. Goliath: Can Trade Preferences to Small Countries Stop Multilateral Liberalization?," University of Maryland, mimeo. 
MacPhee, Craig R., and Rosenbaum, David I., 1989, "The Asymmetric Effects of Reversible Tariff Changes under the United States GSP," Southern Economic Journal 56 (July): 105-125.

Mattoo, Aaditya, Devesh Roy, Arvind Subramanian. [2003] "The Africa Growth and Opportunity Act and its Rules of Origin: Generosity Undermined?," World Economy, 26(6): 829-52 (June).

McQueen, M (1999) "After Lomé IV: ACP-EU Trade Preferences in the $21^{\text {st }}$ Century," Intereconomics, 34, 223-232

McQueen, M and C. Stevens, (1989), “Trade Preferences and Lomé IV: Non-traditional ACP Exports to the EC," Development Policy Review Vol. 7, pp. 239-260.

Melamed, Claire (2003) Doing 'Development' at the World Trade Organization: the Doha Round and special and differential treatment', IDS Bulletin Vol. 34, No 2.

Michalopoulos, Constantine (2000) 'Trade and Development in the GATT and WTO: The Role of Special and Differential Treatment for Developing Countries', World Economy

Marcus and Howard Pack, 2003. Industrial Policy in an Era of Globalization: Lessons from Asia (Washington, DC: Institute of International Economics).

McCulloch, Neil, L. Alan Winters and Xavier Cirera. 2001. Trade Liberalization and Poverty: a Handbook (London: Centre for Economic Policy Research).

OECD. 1997. "Market Access for the Least Developed Countries: Where are the barriers?," OCDE/GD(97)174.

Onguglo, Bonapas. 1999. "Developing Countries and Unilateral Trade Preferences in the New International Trading System," in Miguel Rodriguez Mendoza, Patrick Low and Barbara Kotschwar (editors), Trade Rules in the Making: Challenges in Regional and Multilateral Negotiations. Washington, D.C.: The Brookings Institution Press/Organization of American States.

Oyejide, T. Ademola. 2002. "Special and Differential Treatment," in B. Hoekman et al. (eds.), Development, Trade and the WTO: A Handbook Washington DC: World Bank.

Ozden, C. and E. Reinhart. 2003. "First Do No Harm: GSP and The Effect of Trade Preferences on Developing Country Exports," World Bank, mimeo.

Özden, C. and Gunjan Sharma (2004) Price Effects of Preferential Market Access: the Caribbean Basin initiative and the apparel sector. World Bank Policy Research Working Paper 3244.

Page, Sheila and Michael Davenport. 1994. "Effects of the GATT Uruguay Round on Developing Countries," Overseas Development Institute, Mimeo

Page, Sheila and Peter Kleen. 2004. "Special and Differential Treatment of Developing Countries in the World Trade Organization," report for the Ministry of Foreign Affairs, Sweden.

Panagariya, Arvind. 2003a. "Miracles and Debacles: Do Free Trade Skeptics Have a Case?," mimeo.

Panagariya, Arvind. 2003b. "Aid Through Trade: An Effective Option?," mimeo.

Pangestu, Mari. 2000. 'Special and Differential Treatment in the Millennium: Special for Whom and How Different?' The World Economy 23(9), 1285-1302.

Pelzman, J., and G. Schoepfle. 1988. "The Impact of the Caribbean Basin Economic Recovery Act on Caribbean Nations' Exports and Development," Economic Development and Cultural Change 38: 753-96 (July).

Romalis, J., 2003, "Would Rich Country Trade Preferences Help Poor Countries Grow?" http://gsbwww.uchicago.edu/fac/john.romalis/research/gspgrowth.pdf

Rousslang, Donald and John Lindsay. 1984., "The Benefits to Caribbean Basin Countries from the US CBI Tariff Elimination," Journal of Policy Modeling 6(4): 513-30.

Srinivasan, T. N. and Jagdish Bhagwati. 2001. "Outward-Orientation and Development: Are Revisionists Right?" in Trade, Development and Political Economy: Essays in Honour of Anne O. Krueger. Deepak Lal and R. H. Snape, eds. London: Palgrave, pp. 3-26. 
Stevens, Christopher. 2002. "The Future of SDT for Developing Countries in the WTO," Institute for Development Studies, Sussex, Working Paper 163 (May).

Tangermann, S., 2002 The Future of Preferential Trade Arrangements for Developing Countries and the Current Round of WTO Negotiations on Agriculture, Rome: FAO.

UNCTAD (1999), "Quantifying the Benefits Obtained by Developing Countries from the Generalized System of Preferences", mimeo.

UNCTAD (2003) Trade Preferences for LDCs: an early assessment of benefits and possible improvements, New York and Geneva: United Nations.

Wang, Zhen Kun and Winters, 2000. Putting “Humpty” Together Again: Including Developing Countries in a Consensus for the WTO, CEPR Policy Paper No. 4 (London: Centre for Economic Policy Research).

Weston, A. (1995), "The Uruguay Round - Costs and Compensation for Developing Countries," Geneva: UNCTAD.

Winters, L. A. 2004. “Adjustment Assistance for Trade Liberalization,” mimeo.

Yeats, A., 1995, "What are OECD Trade preferences Worth to Sub-Saharan Africa?," African Studies Review, Vol. 38, April, pp. 81-101. 


\title{
Annex: Trade Preferences and Differential Treatment of Developing Countries
}

\author{
Bernard Hoekman and Çaglar Özden, Editors
}

Table of Contents

\section{History / Early Ideas and Assessments}

UNCTAD [1964], Towards a New Trade Policy for Development, Report by the Secretary General of United Nations Conference on Trade and Development, United Nations, New York. (Part 2, Ch. II \& parts of Part 3 Sections $C \& D$ )

Part IV GATT (1965) and the Enabling Clause (GATT) [1979]

Patterson, Gardner [1965], "Would Tariff Preferences Help Economic Development?," Lloyds Bank Review, vol. 76, pp. 18-30.

Johnson, Harry G [1967], Economic Policies Toward Less Developed Countries, Brookings (Portions of chapter 6)

Finger, J.M. and Mordecai Kreinin. [1976]. "A New International Economic Order: A Critical Survey of the Issues," Journal of World Trade Law, 16(6) November.

Hudec, Robert E. [1987], Developing Countries in the GATT Legal System, Thames Essay \#50. Gower. (Portions of Chapters 4,5,6,11)

\section{Economic Analysis}

Cooper, Richard [1972], “The European Community's System of Generalized Tariff Preferences: A Critique," Journal of Development Studies v 8, n 4, p. 379-94

Murray, Tracy [1973], "How Helpful is The Generalized System of Preferences to Developing Countries?," Economic Journal, vol. 83, p . 449-55.

Baldwin R. and T. Murray [1977], "MFN Tariff Reductions and LDC Benefits under the GSP," Economic Journal, p. 30-46.

Sapir, André. [1981], "Trade Benefits under the EEC Generalized System of Preferences," European Economic Review vol. 15, no. 3 (March): 339-55.

Sapir, A. and L. Lundberg [1984], "The U.S. Generalized System of Preferences and Its Impacts," in A.O. Krueger and R.E. Baldwin (eds.) The Structure and Evolution of US Trade Policy, NBER.

Brown, Drusilla K. [1987], "General Equilibrium Effects of the US Generalized System of Preferences," Southern Economic Journal 54: 27-47.

Clark, Don P., and Zarrilli, Simonetta [1992], "Non-Tariff Measures and Industrial Nation Imports of GSP-Covered Products," Southern Economic Journal 59: 284-293 (October).

Devault, James [1996] "Competitive Need Limits and the US Generalized System of Preferences," Contemporary Economic Policy, vol.14, pp.58-65

\section{Administrative Costs}

Herin, Jan. [1986], 'Rules of Origin and Differences between Tariff Levels in EFTA and in the EC', Occasional Paper no. 13 (Geneva: EFTA).

Brenton, Paul and Miriam Manchin. 2003. "Making EU Trade Agreements Work: The Role of Rules of Origin," The World Economy, 26, 755-769.

Stevens, Chris and Jane Kennan. [2004]. "Making Preferences More Effective". Institute for Development Studies briefing paper. 


\section{Political Economy}

McCulloch, Rachel and Jose Pinera. [1977], "Trade as Aid: The Political Economy of Tariff Preferences for Developing Countries," American Economic Review, vol. 67, no.5, p. 959-67.

Ray, Edward John [1987], "The Impact of Special Interests on Preferential Tariff Concessions by the United States," Review of Economics and Statistics 69 (May): 187-193.

Olarreaga Marcelo and Caglar Ozden. (2004), "AGOA and Apparel: Who Captures the Tariff Rent in the Presence of Preferential Market Access?", The World Economy, [forthcoming].

Ozden, Caglar and Eric Reinhardt. [2005] "The Perversity of Preferences: The Impact of the GSP on Developing Country Trade Policies, 1976-2000," Journal of Development Economics, forthcoming.

\section{Preference erosion}

Ahmad, Jaleel [1977], "Tokyo Rounds of Trade Negotiations and the Generalized System of Preferences," Economic Journal, vol. 88, p. 285-95.

Yamazaki, F., [1996], "Potential Erosion of Trade Preferences in Agricultural Products," Food Policy, Vol. 21, pp. 409-18.

Alexandraki, Katerina and Hans Peter Lankes [2004] "Estimating the Impact of Preference Erosion on Middle-Income Countries," IMF Working Paper, Washington, DC: IMF.

\section{International Cooperation, GATT/WTO Developments and Proposals for Reform}

Wolf, M. [1984], 'Two-Edged Sword: Demands of Developing Countries and the Trading System', in J. Bhagwati, and G. Ruggie, Power, Passions and Purpose: Prospects for North-South Negotiations (Cambridge, Mass.: MIT Press).

Hindley, Brian. [1987], 'Different and more favorable treatment - and graduation', in J. M. Finger, and A. Olechowski (eds.), The Uruguay Round: A Handbook for the Multilateral Trade Negotiations (Washington DC: The World Bank).

Whalley, John. [1999]. "Special and Differential Treatment in the Millennium Round," The World Economy 22(8), 1065-1093.

Prowse, S (2002) 'The Role of International and National Agencies in Trade-related Capacity Building', The World Economy, 23, 9: 1285-1302.

Stevens, C. (2003) 'If One Size Doesn't Fit All, What Does? Rethinking special and differential treatment in the World Trade Organization', IDS Bulletin Vol. 34 No 2.

Hoekman, Michalopoulos, Winters [2004], "Differential and More Favorable Treatment, Reciprocity and Fuller Participation of Developing Countries: Objectives, Instruments and Options for the WTO," World Economy. Vol. 27, pp. 481-506. 